\title{
The effect of financial development on income inequality in Turkey: An estimate of the Greenwood- Jovanovic hypothesis
}

\author{
Emrah Koçak, ${ }^{1}$ Nısfet Uzay ${ }^{2}$
}

\begin{abstract}
This paper is the first to examine the linear and nonlinear effect of financial development on income inequality in Turkey over the period of 1980-2013. Financial development is represented by disaggregated and aggregated indicators. In this way, the effects of various financial indicators on income inequality are explained. Maki (2012) structural breaks co-integration test, and Stock and Watson (1993) dynamic ordinary least squares (DOLS) methods are followed for empirical analysis. Finally, the fully modified least squares (FM-OLS) regression analysis method developed by Philips and Hansen (1990) is used for robustness check. The estimation results of the linear relationship indicate that financial development is a mitigating effect on income inequality. These results support the inequality-narrowing hypothesis. The non-linear relationship results show that financial development first increases income inequality but after financial development reaches a certain level, this effect is reversed and financial development reduces income inequality. These results support the GreenwoodJovanovic hypothesis. All the results strongly suggest that financial development is a mitigating or improving effect on income inequality over the long-run.
\end{abstract}

Keywords: Financial development, Income inequality, Greenwood-Jovanovic hypothesis, Turkey.

\section{JEL Classification:}

Received: 21 September 2018 / Accepted: 4 October 2019 / Sent for Publication: 5 December 2019

\section{Introduction}

There is a tremendous literature on the relationship between financial development and economic growth. Levin (2005) provides a broad literature review on the theoretical and empirical framework for the link between financial development and economic growth. It is emphasized that an advanced financial system reduces capital/borrowing costs, allocates capital to more efficient channels, and drives economic growth. While the relevant literature provides important evidence for the relationship between financial development and economic growth, there is a lack of research on how financial

\footnotetext{
${ }^{1}$ Erciyes University, Faculty of Economics and Administrative Sciences, Department of Economics, Kayseri, Turkey, emrahkocak@erciyes.edu.tr

${ }^{2}$ Erciyes University, Faculty of Economics and Administrative Sciences, Department of Economics, Kayseri, Turkey, uzay@erciyes.edu.tr
}

(C) 2019 by the authors; licensee Review of Economic Perspectives / Národohospodářský obzor, Masaryk University, Faculty of Economics and Administration, Brno, Czech Republic. This article is an open access article distributed under the terms and conditions of the Creative Commons Attribution 3.0 license, Attribution - Non Commercial - No Derivatives. 
development affects poverty and inequality (Fowowe and Abidoye 2013; Pardo and Sánchez Santos 2014; Akinboade et al. 2014). On the other hand, rising global income inequality has become a widespread concern (Sutter 2009, 2010; Wallerstein et al. 2015, Lee and Lee 2018). The literature has recently begun to draw attention to the effect of financial development on income inequality (Haan and Sturm 2017). The current literature presents three disparate hypotheses regarding the relationship between financial development and income inequality. The first is the inequality-widening hypothesis that indicates that financial development is a cause of an enhancing / expanding influence on income inequality. This hypothesis emphasizes that in countries with particularly weak institutions, people with rich and good connections might benefit from the process of financial development. The financial system generally directs funds to people that are rich, easily able to offer collateral and are more likely to pay credits. As the financial sector continues to grow, the rich get more funding from this sector. However, the poor, who do not offer collateral, are neglected and may not receive credit or debt from this sector. As a result of this tendency, poor people do not get adequate financial services. For this reason, it is much harder for the poor to migrate to cities, spend enough money on human capital or education and start a new business (Clarke et al. 2006). Eventually, the poor are only equipped with primary education and participate in the unskilled labor market with low wages (Ahmed and Masih 2017).

The second is the inequality-narrowing hypothesis, which indicates that financial development is a mitigating effect on income inequality. This hypothesis, proposed by Galor and Zeira (1993) and Banerjee and Newman (1993), implies that the development of the financial sector will facilitate the access of the poor to the loans. Such a financial system might provide equal opportunities for talented and ambitious low-income individuals (Law and Tan 2009). Individuals are considered to inherit wealth at different levels. It is stated that those with greater wealth have invested more in education and have directed more qualified work. On the other side, individuals with less initial wealth have to invest in human capital to reach higher incomes. In an underdeveloped financial system where borrowing is difficult and costly, poor individuals will not be able to find credit for human capital investments. Moreover, this structure will continue for new generations. Poverty will be transferred to other generations as well. Therefore, as the financial system grows and develops, wider credit opportunities emerge. The poor might access opportunities to credit for human capital investments and increase their potential to start their own business and gain earnings (Abosedra et al. 2016; Ahmed and Masih 2017). Consequently, income inequality decreases with the development of the financial sector.

The third hypothesis, called the Greenwood-Jovanovic hypothesis and based on the theoretical approach of Kuznets (1955), indicates that there is a non-linear relationship between financial development and income inequality. According to this approach, financial markets are growing very slowly in the early stages of economic development. Due to the insufficient financial infrastructure at this stage, only the rich might access credit facilities. In the middle stages of the economic development process, the financial superstructure begins to emerge, economic growth and savings grow, and rich people benefit much more from this process of progress. The inequality between the poor and the rich begins to expand. In the last stage of economic development (maturity phase), financial markets have reached a certain volume, the infrastructure required for financial 
services has been established, and credit facilities have become accessible to all individuals, including poor individuals. As the financial system reaches a certain level of development, the development of the financial system begins to cause a mitigating effect on income inequality (Greenwood and Jovanovic 1990). This relationship between financial development and income inequality is also called the inverted Ushaped hypothesis.

The aim of this paper is to determine the relationship between financial development and income inequality in Turkey during the period 1980-2013. Turkey has embarked on a process of structural transformation in the economy since 1980. In the last 40 years, the country has significantly liberalized, rapidly urbanized in the field of foreign trade and finance, and displayed a significant growth performance in employment and per capita income (Koçak and Şarkgüneşi 2018). According to the World Bank 2019 reports, Turkey has a population of 78.6 million, a GDP of 851 billion dollars, and 9,631-dollar income per capita in 2018. Another remarkable development in this development process is the observed decrease in income inequality. According to Güven et al. (2016), while the Gini coefficient was 0.49 in 1994, it decreased to 0.40 in 2000 and 0.38 in 2005 and was realized as 0.40 in 2012. Although the downward trend in the Gini coefficient is a positive development in Turkey, the value of the coefficient is still quite high compared to developed countries. This shows that income inequality is an important problem that needs to be solved. In this context, this paper tries to answer whether there is a significant effect of financial development on income inequality in Turkey. The contribution of this paper is threefold: (1) Financial development is represented by four indicators. These indicators are deposits money assets of banks, deposits of the financial system, domestic credits, and broad money supply. In addition, these indicators are aggregated and a financial development index is produced by principal component analysis (PCA). The effects of financial development on income inequality are estimated both by disaggregated and aggregated indicators. Thus, the effects of different financial development indicators on income inequality are explained in a more comprehensive way. (2) As far as we know, there is no empirical research examining the relationship between financial development and income inequality in Turkey (see table 1). This paper fills the gap in the literature. (3) The third possible contribution of this study is the empirical method. This paper uses recently developed Maki (2012) structural breaks co-integration test and dynamic least squares estimator (DOLS). These methods have the following important advantages: (a) In economic life, there are many structural elements such as economic crises, technological shocks, institutional developments, policy and regime changes that may affect the relationship between variables. Conventional co-integration tests that do not consider structural breaks into account have a lower estimate power. (b) The long-term relationship between variables is the focus of many pieces of research. However, the data used for the researchers to produce effective estimates must have asymptotic properties. On the other hand, researchers generally do not have data to justify asymptotic theories. For example, the conventional least squares (OLS) estimator produces biased estimates in small samples. In addition, regression estimates using small samples may cause an endogeneity problem. In this case it is important to use alternative estimation methods that produce unbiased results in small samples (Montalvo 1995). Therefore, this study, which estimates with 34-year data, follows the DOLS method developed by Stock and Watson (1993) for regression estimation. The DOLS estimator produces unbiased 
results in small samples and is free from serial correlation and endogeneity (Masih and Masih 1996; Al-Azzam and Hawdon, 1999; Irffi et al. 2008; Ahmad et al. 2017; Koçak and Şarkgüneşi 2018). Thus, this study will provide robust results for the relationship between financial development and income inequality.

The rest of the work is organized as follows: Section 2 reveals the literature findings. Section 3 exhibits model, data and methodology. Section 4 presents the production of the financial development index for Turkey. Section 5 reports estimation results and discussion. Finally, section 6 indicates summary findings and conclusions.

\section{Empirical Literature}

Although the theoretical literature on the relationship between financial development and income inequality goes backward (Greenwood and Jovanovic 1990; Banerjee and Newman 1993; Galor and Zeira 1993), the empirical literature has recently improved. Empirical studies are seen to cover a period of about 15 years. The first reason for these developments is the calculation of new income inequality indicators for countries in recent years. With this data, researchers are able to conduct further studies on income inequality in underdeveloped and developing countries. For example, the Texas Inequality Project (UTIP) sets out a calculation method to measure and explain the movements of inequalities in wages and earnings in the world. The data set, called the Estimated Household Income Inequality (EHII), provides income inequality indicators covering the period 1963 to 2015 for 151 countries. In addition, the World Income Inequality Database (WIID) provides comprehensive statistics on income inequality for approximately 172 developed, developing and transition countries. Finally, Solt (2009) develops the data set called the Standardized World Income Inequality Database (SWIID). This method is developed to solve the data problem for countries. Because international research on the causes and consequences of income inequality has been inadequate due to limitations of existing data sets. SWIID produces indicators such as gross and net income inequality for 192 countries. The second reason for the recent development in the literature is the advances in econometric estimation methods.

This study examines the twenty-seven studies in the relatively new literature (see table 1) and reaches the following observations: (a) The econometric estimation models are built in three groups. The first group investigates the relationship between financial development and income inequality within a linear model (Beck et al. 2004; Law and Tan 2009; Ang 2010; Bittencourt 2010; Kappel 2010; Mookerjee and Kalipioni 2010; Jalil and Feridun 2011; Kim and Lin 2011; Ling-Zheng and Xia-Hai 2012; Fowowe and Abidoye 2013; Prete 2013; Tiwari et al. 2013; Kunieda 2014; Law et al. 2014; Sehrawat and Giri 2016; De Haan and Sturm 2017). The second group estimates the relationship between financial development and income inequality within a nonlinear model (Satti et al. 2015; Azzam and Ali Raza 2018; Younsi and Bechtini 2018). The third group examines the relationship between financial development and income inequality both within the linear and nonlinear models (Clarke et al. 2006; Liang 2008; Batuo et al. 
2010; Shahbaz and Islam 2011; Shahbaz et al. 2015; Jauch and Watzka 2016; Bittencourt et al. 2018).

(b) Models are estimated by panel data methods such as co-integration, DOLS, fixed effects (FE), random effects (RE), instrumental variables (IV), two-step least squares (2SLS) and generalized method of moments (GMM). Single-country surveys often use time series analysis methods such as autoregressive distributed lag estimation (ARDL). Fewer studies use the threshold regression method (Kim and Lin 2011; Ling-Zheng and Xia-Hai 2012; Law et al. 2014).

Table 1. Literature on the relationship between financial development and income inequality

\begin{tabular}{|c|c|c|c|c|}
\hline Author(s) & Country & Period & Methodology & Conclusion \\
\hline $\begin{array}{l}\text { Beck et al. } \\
\text { (2004) }\end{array}$ & $\begin{array}{l}\text { (a) } 52 \text { developed } \\
\text { and developing } \\
\text { countries } \\
\text { (b) } 58 \\
\text { developing } \\
\text { countries }\end{array}$ & $\begin{array}{l}\text { (a) } 1960- \\
1989 \\
\text { (b) } 1980- \\
2000\end{array}$ & $\begin{array}{l}\text { Panel OLS, } \\
\text { IV }\end{array}$ & $\begin{array}{l}\text { The inequality- } \\
\text { narrowing hypothesis } \\
\text { is supported. }\end{array}$ \\
\hline $\begin{array}{l}\text { Clarke et al. } \\
(2006)\end{array}$ & 83 countries & $\begin{array}{l}1960- \\
1995\end{array}$ & $\begin{array}{l}\text { Panel OLS, } \\
\text { 2SLS, RE, IV }\end{array}$ & $\begin{array}{l}\text { The inequality- } \\
\text { narrowing hypothesis } \\
\text { is supported. } \\
\text { The Greenwood- } \\
\text { Jovanovic hypothesis } \\
\text { is rejected. }\end{array}$ \\
\hline Liang (2008) & $\begin{array}{l}\text { China } \\
\text { (Provincial- } \\
\text { level) }\end{array}$ & $\begin{array}{l}1991- \\
2000\end{array}$ & GMM & $\begin{array}{l}\text { The inequality- } \\
\text { narrowing hypothesis } \\
\text { is supported. } \\
\text { The Greenwood- } \\
\text { Jovanovic hypothesis } \\
\text { is rejected. }\end{array}$ \\
\hline $\begin{array}{l}\text { Law and Tan } \\
\text { (2009) }\end{array}$ & Malaysia & $\begin{array}{l}1980- \\
2000\end{array}$ & ARDL & $\begin{array}{l}\text { There is no significant } \\
\text { relationship between } \\
\text { financial development } \\
\text { and income inequality. }\end{array}$ \\
\hline Ang (2010) & India & $\begin{array}{l}1951- \\
2004\end{array}$ & ARDL & $\begin{array}{l}\text { The inequality- } \\
\text { narrowing hypothesis } \\
\text { is supported. }\end{array}$ \\
\hline $\begin{array}{l}\text { Batuo et al. } \\
(2010)\end{array}$ & $\begin{array}{l}22 \text { African } \\
\text { countries }\end{array}$ & $\begin{array}{l}1990- \\
2004\end{array}$ & GMM & $\begin{array}{l}\text { The inequality- } \\
\text { narrowing hypothesis } \\
\text { is supported. } \\
\text { The Greenwood- } \\
\text { Jovanovic hypothesis } \\
\text { is rejected. }\end{array}$ \\
\hline
\end{tabular}




\begin{tabular}{|c|c|c|c|c|}
\hline $\begin{array}{l}\text { Bittencourt } \\
(2010)\end{array}$ & $\begin{array}{l}\text { Brazil } \\
\text { (6 Major } \\
\text { regions) }\end{array}$ & $\begin{array}{l}1985- \\
1994\end{array}$ & Panel OLS & $\begin{array}{l}\text { The inequality- } \\
\text { narrowing hypothesis } \\
\text { is supported. }\end{array}$ \\
\hline $\begin{array}{l}\text { Kappel } \\
(2010)\end{array}$ & $\begin{array}{l}78 \text { developed } \\
\text { and developing } \\
\text { countries }\end{array}$ & $\begin{array}{l}1960- \\
2006\end{array}$ & $\begin{array}{l}\text { Panel OLS, } \\
2 \text { SLS }\end{array}$ & $\begin{array}{l}\text { The inequality- } \\
\text { narrowing hypothesis } \\
\text { is supported. }\end{array}$ \\
\hline $\begin{array}{l}\text { Mookerjee } \\
\text { and Kalipioni } \\
(2010)\end{array}$ & $\begin{array}{l}115 \text { developed } \\
\text { and developing } \\
\text { countries }\end{array}$ & $\begin{array}{l}2000- \\
2005\end{array}$ & $\begin{array}{l}\text { Panel OLS, } \\
\text { IV }\end{array}$ & $\begin{array}{l}\text { The inequality- } \\
\text { narrowing hypothesis } \\
\text { is supported. }\end{array}$ \\
\hline $\begin{array}{l}\text { Jalil and } \\
\text { Feridun } \\
(2011)\end{array}$ & China & $\begin{array}{l}1978- \\
2006\end{array}$ & ARDL & $\begin{array}{l}\text { The inequality- } \\
\text { narrowing hypothesis } \\
\text { is supported. }\end{array}$ \\
\hline $\begin{array}{l}\text { Kim and Lin } \\
(2011)\end{array}$ & 72 countries & $\begin{array}{l}1960- \\
2005\end{array}$ & $\begin{array}{l}\text { Threshold } \\
\text { regressions }\end{array}$ & $\begin{array}{l}\text { The inequality- } \\
\text { narrowing hypothesis } \\
\text { is supported. }\end{array}$ \\
\hline $\begin{array}{l}\text { Shahbaz and } \\
\text { Islam (2011) }\end{array}$ & Pakistan & $\begin{array}{l}1971- \\
2005\end{array}$ & ARDL & $\begin{array}{l}\text { The inequality- } \\
\text { narrowing hypothesis } \\
\text { is supported. } \\
\text { The Greenwood- } \\
\text { Jovanovic hypothesis } \\
\text { is rejected }\end{array}$ \\
\hline $\begin{array}{l}\text { Ling-Zheng } \\
\text { and Xia-Hai } \\
(2012)\end{array}$ & $\begin{array}{l}\text { China } \\
\text { (Provincial- } \\
\text { level) }\end{array}$ & $\begin{array}{l}1996- \\
2009\end{array}$ & $\begin{array}{l}\text { Threshold } \\
\text { regressions }\end{array}$ & $\begin{array}{l}\text { The inequality- } \\
\text { widening hypothesis is } \\
\text { supported. }\end{array}$ \\
\hline $\begin{array}{l}\text { Fowowe and } \\
\text { Abidoye } \\
(2013)\end{array}$ & $\begin{array}{l}27 \text { African } \\
\text { countries }\end{array}$ & $\begin{array}{l}1981- \\
2005\end{array}$ & $\begin{array}{l}\text { Panel OLS, } \\
\text { GMM }\end{array}$ & $\begin{array}{l}\text { There is no significant } \\
\text { relationship between } \\
\text { financial development } \\
\text { and income inequality. }\end{array}$ \\
\hline Prete (2013) & 30 countries & $\begin{array}{l}1980- \\
2005\end{array}$ & Panel OLS & $\begin{array}{l}\text { The inequality- } \\
\text { narrowing hypothesis } \\
\text { is supported. }\end{array}$ \\
\hline $\begin{array}{l}\text { Tiwari et al. } \\
\text { (2013) }\end{array}$ & India & $\begin{array}{l}1965- \\
2008\end{array}$ & ARDL & $\begin{array}{l}\text { The inequality- } \\
\text { widening hypothesis is } \\
\text { supported. }\end{array}$ \\
\hline $\begin{array}{l}\text { Kunieda et } \\
\text { al. (2014) }\end{array}$ & 119 countries & $\begin{array}{l}1985- \\
2009\end{array}$ & $\begin{array}{l}\text { Panel OLS, } \\
\text { IV, GMM }\end{array}$ & $\begin{array}{l}\text { (1) The inequality- } \\
\text { widening hypothesis is } \\
\text { supported (if financial } \\
\text { markets are open to } \\
\text { world markets at a } \\
\text { high level). } \\
\text { (2) The inequality- } \\
\text { narrowing hypothesis } \\
\text { is supported (if } \\
\text { financial markets are } \\
\text { closed to world }\end{array}$ \\
\hline
\end{tabular}




\begin{tabular}{|c|c|c|c|c|}
\hline & & & & $\begin{array}{l}\text { markets at a high } \\
\text { level). }\end{array}$ \\
\hline $\begin{array}{l}\text { Law et al. } \\
(2014)\end{array}$ & 81 countries & $\begin{array}{l}1985- \\
2010\end{array}$ & $\begin{array}{l}\text { Threshold } \\
\text { regressions }\end{array}$ & $\begin{array}{l}\text { The inequality- } \\
\text { narrowing hypothesis } \\
\text { is supported } \\
\text { (After reaching a } \\
\text { certain level of } \\
\text { institutional } \\
\text { development) }\end{array}$ \\
\hline $\begin{array}{l}\text { Shahbaz et } \\
\text { al. (2015) }\end{array}$ & Iran & $\begin{array}{l}1965- \\
2011\end{array}$ & ARDL & $\begin{array}{l}\text { The inequality- } \\
\text { narrowing hypothesis } \\
\text { is supported. } \\
\text { The Greenwood- } \\
\text { Jovanovic hypothesis } \\
\text { is supported. }\end{array}$ \\
\hline $\begin{array}{l}\text { Satti et al. } \\
(2015)\end{array}$ & Kazakhstan & $\begin{array}{l}1991- \\
2011\end{array}$ & & $\begin{array}{l}\text { The Greenwood- } \\
\text { Jovanovic hypothesis } \\
\text { is rejected. }\end{array}$ \\
\hline $\begin{array}{l}\text { Sehrawat and } \\
\text { Giri (2016) }\end{array}$ & $\begin{array}{l}11 \text { south Asian } \\
\text { countries }\end{array}$ & $\begin{array}{l}1990- \\
2013\end{array}$ & $\begin{array}{l}\text { Panel co- } \\
\text { integration, } \\
\text { Panel DOLS }\end{array}$ & $\begin{array}{l}\text { The inequality- } \\
\text { widening hypothesis is } \\
\text { supported }\end{array}$ \\
\hline $\begin{array}{l}\text { Jauch and } \\
\text { Watzka } \\
(2016)\end{array}$ & $\begin{array}{l}138 \text { developed } \\
\text { and developing } \\
\text { countries }\end{array}$ & $\begin{array}{l}1960- \\
2008\end{array}$ & & $\begin{array}{l}\text { The inequality- } \\
\text { widening hypothesis is } \\
\text { supported. } \\
\text { The Greenwood- } \\
\text { Jovanovic hypothesis } \\
\text { is partially supported. }\end{array}$ \\
\hline $\begin{array}{l}\text { De Haan and } \\
\text { Sturm (2017) }\end{array}$ & 121 countries & $\begin{array}{l}1975- \\
2005\end{array}$ & Panel RE & $\begin{array}{l}\text { The inequality- } \\
\text { widening hypothesis is } \\
\text { supported. }\end{array}$ \\
\hline $\begin{array}{l}\text { Ahmed and } \\
\text { Masih (2017) }\end{array}$ & Malaysia & $\begin{array}{l}1970- \\
2007\end{array}$ & ARDL & $\begin{array}{l}\text { There is no significant } \\
\text { relationship between } \\
\text { financial development } \\
\text { and income inequality. }\end{array}$ \\
\hline $\begin{array}{l}\text { Azam and } \\
\text { Ali Raza } \\
(2018)\end{array}$ & $\begin{array}{l}\text { ASEAN-5 } \\
\text { Countries }\end{array}$ & $\begin{array}{l}1989- \\
2013\end{array}$ & $\begin{array}{l}\text { Panel co- } \\
\text { integration, } \\
\text { FE }\end{array}$ & $\begin{array}{l}\text { The Greenwood- } \\
\text { Jovanovic hypothesis } \\
\text { is supported. }\end{array}$ \\
\hline $\begin{array}{l}\text { Younsi and } \\
\text { Bechtini } \\
(2018)\end{array}$ & $\begin{array}{l}\text { BRICS } \\
\text { countries }\end{array}$ & $\begin{array}{l}1995- \\
2015\end{array}$ & $\begin{array}{l}\text { Panel co- } \\
\text { integration, } \\
\text { POLS, FE, } \\
\text { GMM }\end{array}$ & $\begin{array}{l}\text { The Greenwood- } \\
\text { Jovanovic hypothesis } \\
\text { is supported. }\end{array}$ \\
\hline $\begin{array}{l}\text { Bittencourt et } \\
\text { al. (2018) }\end{array}$ & $\begin{array}{l}\text { USA } \\
\text { (State level) }\end{array}$ & $\begin{array}{l}1976- \\
2011\end{array}$ & $\mathrm{FE}$ & $\begin{array}{l}\text { The inequality- } \\
\text { widening hypothesis is } \\
\text { supported (High- } \\
\text { income inequality }\end{array}$ \\
\hline
\end{tabular}


states).

The Greenwood-

Jovanovic hypothesis

is supported (Low-

income inequality

states).

(c) When the literature results are evaluated, it is seen that there is no consensus in the researches. The results of the researches differ according to the countries, the periods and the estimation methods. The results of the studies show that $50 \%$ supported the inequality-narrowing hypothesis, $23 \%$ the inequality-widening hypothesis, $17 \%$ the Greenwood-Jovanovic hypothesis, and $10 \%$ neutrality hypothesis (see figure 1).

\section{Figure 1. Distribution of literature results (\%)}

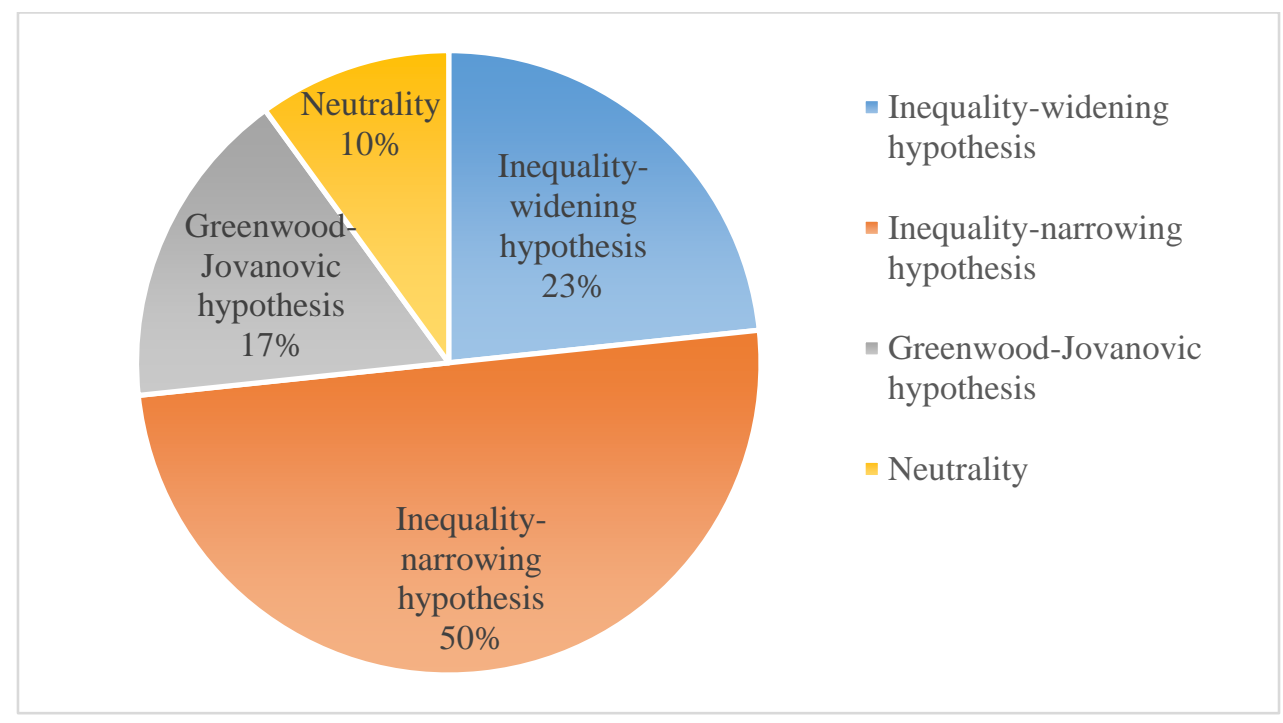

Source: Own processing

(d) Among the non-methodological reasons for the lack of a common consensus in the literature findings, differences in economic structure, institutional quality, and development levels among countries can be shown. Kunieda et al. (2014) show that the effect of financial development on income inequality varies according to the openness structure of the financial markets in the country. Law et al. (2014) demonstrate that the mitigating effect of financial development on income inequality is driven by a certain improvement in institutional quality. Beck et al. (2004), Kappel (2010), Mookerjee and Kalipioni (2010) and Jauch and Watzka (2016) provide evidence that the impact of financial development on income inequality may vary according to the level of development of their countries. 
(e) As mentioned earlier, there are no studies in the literature investigating the financial development and income inequality relations in Turkey. However, in some multicountry panel data research, Turkey is examined in the developing countries group (Kim and Lin 2011; Law et al. 2014; De Haan and Sturm 2017). There is also no consensus in these researches on the relationship between financial development and income inequality in developing countries (including Turkey).

\section{Model, Data and Methodology}

In this study, the following model is estimated for the determination of the relationship between financial development and income inequality:

$\mathrm{INQ}_{\mathrm{t}}=\beta_{0}+\beta_{1} \mathrm{Y}_{\mathrm{t}}+\beta_{2}$ Trade $_{\mathrm{t}}+\beta_{3} \operatorname{Modern}_{\mathrm{t}}+\beta_{4} \mathrm{INF}_{\mathrm{t}}+\beta_{5} \mathrm{FDI}_{\mathrm{t}}+\varepsilon_{\mathrm{t}}$

Here, INQ, FDI, $\mathrm{t}$ and $\varepsilon$ denote dependent variable (income inequality), explanatory variable (financial development), time period $(\mathrm{t}=1980, \ldots, 2013)$ and error term, respectively. $\beta_{0}$ is a constant term and $\beta_{1}, \beta_{2}, \ldots, \beta_{5}$ denote the coefficient parameters of the variables. The reason for selecting the data in a limited time period (1980-2013) is related to the accessibility of data for income inequality. Y, Trade, Modern and INF, which are added as model control variables, show economic growth, trade, industrialization (representing modernization) and inflation. Table 2 summarizes the definitions of variables and data sources. Prior to the analysis, the logarithm transformation of all data is performed to achieve more consistent and unbiased results. This reduces the skew in the data and softens the change in variance (Changyong et al. 2014). In addition, nonlinear relationships can be captured in regression by expressing dependent and / or independent variables in terms of natural logarithms.

Table 2. Definitions of variables and data sources

\begin{tabular}{|c|c|c|c|c|}
\hline $\begin{array}{c}\text { Dependent } \\
\text { Variable }\end{array}$ & Proxy & Unit & Source & Definition \\
\hline $\begin{array}{l}\text { Income } \\
\text { inequality }\end{array}$ & INQ & $\begin{array}{l}\text { Theil } \\
\text { Index } \\
(0-\infty)\end{array}$ & $\begin{array}{l}\text { University of } \\
\text { Texas } \\
\text { Inequality } \\
\text { Project }\end{array}$ & $\begin{array}{l}\text { Theil index is } \\
\text { calculated by } \\
\text { comparing the income } \\
\text { of the people with the } \\
\text { average income of the } \\
\text { population. The } \\
\text { increase in Theil index } \\
\text { value implies an } \\
\text { increase in income } \\
\text { inequality. }\end{array}$ \\
\hline $\begin{array}{c}\text { Explanatory } \\
\text { variables }\end{array}$ & $\begin{array}{l}\text { Proxy } \\
\text { (FD) }\end{array}$ & Unit & Source & Definition \\
\hline $\begin{array}{l}\text { Deposit assets of } \\
\text { the banks }\end{array}$ & Bank-assets & $\begin{array}{l}\% \text { of } \\
\text { GDP }\end{array}$ & $\begin{array}{l}\text { Beck et al., } \\
(2000,2009) ; \\
\text { Čihák et al., } \\
(2012)\end{array}$ & $\begin{array}{l}\text { Deposit money bank } \\
\text { assets to GDP }\end{array}$ \\
\hline
\end{tabular}




\begin{tabular}{|c|c|c|c|c|}
\hline $\begin{array}{l}\text { Total deposits of } \\
\text { the financial } \\
\text { system }\end{array}$ & $\begin{array}{l}\text { Fin- } \\
\text { depositts }\end{array}$ & $\begin{array}{l}\% \text { of } \\
\text { GDP }\end{array}$ & $\begin{array}{l}\text { Beck et al., } \\
(2000,2009) ; \\
\text { Čihák et al., } \\
\text { (2012) }\end{array}$ & $\begin{array}{l}\text { Financial system } \\
\text { deposits to GDP }\end{array}$ \\
\hline $\begin{array}{l}\text { Broad money } \\
\text { supply }\end{array}$ & Money & $\begin{array}{l}\% \text { of } \\
\text { GDP }\end{array}$ & World Bank & $\begin{array}{l}\text { Broad money is the } \\
\text { sum of currency } \\
\text { outside banks; demand } \\
\text { deposits other than } \\
\text { those of the central } \\
\text { government; the time, } \\
\text { savings, and foreign } \\
\text { currency deposits of } \\
\text { resident sectors other } \\
\text { than the central } \\
\text { government; bank and } \\
\text { traveler's checks; and } \\
\text { other securities such as } \\
\text { certificates of deposit } \\
\text { and commercial paper. }\end{array}$ \\
\hline $\begin{array}{l}\text { Domestic credit } \\
\text { to the private } \\
\text { sector }\end{array}$ & Credit & $\begin{array}{l}\% \text { of } \\
\text { GDP }\end{array}$ & World Bank & $\begin{array}{l}\text { Domestic credit to the } \\
\text { private sector refers to } \\
\text { financial resources } \\
\text { provided to the private } \\
\text { sector by financial } \\
\text { corporations, such as } \\
\text { through loans, } \\
\text { purchases of nonequity } \\
\text { securities, and trade } \\
\text { credits and other } \\
\text { accounts receivable, } \\
\text { that establish a claim } \\
\text { for repayment. }\end{array}$ \\
\hline $\begin{array}{l}\text { Financial } \\
\text { Development } \\
\text { Index }\end{array}$ & FDI & $\begin{array}{l}\text { Index } \\
(0-\infty)\end{array}$ & $\begin{array}{l}\text { Produced by } \\
\text { authors }\end{array}$ & $\begin{array}{l}\text { Financial development } \\
\text { index is calculated by } \\
\text { the authors using the } \\
\text { PCA method. }\end{array}$ \\
\hline $\begin{array}{c}\text { Control } \\
\text { variables }\end{array}$ & Proxy & Unit & Source & Definition \\
\hline $\begin{array}{l}\text { Economic growth } \\
\text { (GDP per capita) }\end{array}$ & $\mathrm{Y}$ & $\begin{array}{l}\text { (constant } \\
2010 \text { and } \\
\text { US\$) }\end{array}$ & World Bank & $\begin{array}{l}\text { GDP per capita is } \\
\text { gross domestic product } \\
\text { divided by population. }\end{array}$ \\
\hline Trade openness & Trade & $\begin{array}{l}\% \text { of } \\
\text { GDP }\end{array}$ & World Bank & $\begin{array}{l}\text { Trade is the sum of } \\
\text { exports and imports of } \\
\text { goods and services } \\
\text { measured as a share of } \\
\text { gross domestic } \\
\text { product. }\end{array}$ \\
\hline
\end{tabular}




\begin{tabular}{|c|c|c|c|c|}
\hline $\begin{array}{l}\text { Industrialization } \\
\text { (representing } \\
\text { modernization) }\end{array}$ & Modern & $\begin{array}{l}\% \text { of } \\
\text { GDP }\end{array}$ & World Bank & $\begin{array}{l}\text { Industrialization } \\
\text { includes mining, } \\
\text { manufacturing, } \\
\text { construction, } \\
\text { electricity, water and } \\
\text { natural gas production } \\
\text { and value-added } \\
\text { activities. }\end{array}$ \\
\hline Inflation & INF & annual \% & World Bank & $\begin{array}{l}\text { Inflation is measured } \\
\text { by the change in the } \\
\text { annual consumer price } \\
\text { index. }\end{array}$ \\
\hline
\end{tabular}

Equation (1) is a linear model, and the model's possible estimation results are as follows: (a) If $\beta_{5}=0$ or statistically insignificant, there is no relationship between financial development and income inequality (neutrality). (b) If $\beta_{5}<0$ and statistically significant, financial development has a negative/decreasing effect on income inequality (The inequality-narrowing hypothesis is supported). (c) If $\beta_{5}>0$ and statistically significant, financial development has a positive/increasing effect on income inequality (The inequality-widening hypothesis is supported).

To test the Greenwood-Jovanovic hypothesis, the following nonlinear model is followed:

$\mathrm{INQ}_{\mathrm{t}}=\beta_{0}+\beta_{1} \mathrm{Y}_{\mathrm{t}}+\beta_{2}$ Trade $_{\mathrm{t}}+\beta_{3} \operatorname{Modern}_{\mathrm{t}}+\beta_{4} \mathrm{INF}_{\mathrm{t}}+\beta_{5} \mathrm{FD}_{\mathrm{t}}+\beta_{6} \mathrm{FD}^{2}+\varepsilon_{\mathrm{t}}$

(d) If $\beta_{5}>0$ (and statistically significant) and $\beta_{6}<0$ (and statistically significant), there is an inverse U-shaped relationship between financial development and income inequality. This result supports the Greenwood-Jovanovic hypothesis.

Econometric models are often estimated by ordinary least square method in the literature. The validity of the OLS estimator is only possible if the series used in the analysis are stationary. In the opposite case, the traditional $t$, Wald $F, \mathrm{R}^{2}$ statistics reveal deviated results. Estimation results, applied with non-stationary series, are expressed as spurious regression. For this reason, the stationarity of the series should first be investigated by unit root tests. Traditional unit root tests developed by Dickey and Fuller (ADF, 1981) and Phillips and Perron (PP, 1988) are widely used in econometric literature. According to the unit root test results, if the series are not stationarity in the level values $[\mathrm{I}(0)]$, the first differences of the series are taken, and unit root tests are applied again. If the series are stationary at first difference [I(1)], the cointegration relation must be investigated before estimating their coefficients. Engle and Granger (1987), Johansen (1988, 1990) and Pesaran et al. (2001) co-integration tests are frequently used in the literature. However, these methods do not consider structural changes or structural breaks that occur in a certain period of time. Gregory and Hansen (1996), Hatemi-J (2008) and Maki (2012) have developed co-integration tests that 
consider structural breaks as an alternative to traditional co-integration tests. This study focuses on the relatively new method of Maki (2012) co-integration test.

Maki (2012) calculates a possible breakpoint and t-statistics for each period in the time interval of the sample. To test co-integration under the assumption of multiple breakpoints, use the following models:

$$
\begin{aligned}
& y_{t}=\mu+\sum_{i=1}^{k} \mu_{i} D_{i, t}+\beta^{\prime} x_{t}+\mu_{t} \\
& y_{t}=\mu+\sum_{\substack{k=1 \\
k}}^{k} \mu_{i} D_{i, t}+\gamma t+\beta^{\prime} x_{t}+\mu_{t} \\
& y_{t}=\mu+\sum_{i=1}^{k} \mu_{i} D_{i, t}+\beta^{\prime} x_{t}+\sum_{i=1}^{k} \beta_{i}^{\prime} x_{t} D_{i, t}+\mu_{t} \\
& y_{t}=\mu+\sum_{i=1}^{k} \mu_{i} D_{i, t}+\gamma t+\sum_{i=1}^{k} \gamma_{i} D_{i, t}+\beta_{i}^{\prime} x_{t}+\sum_{i=1}^{k} \beta_{i}^{\prime} x_{t} D_{i, t}+u_{t}
\end{aligned}
$$

$\mathrm{t}=1,2, \ldots ., \mathrm{T} . y_{t}$ and $x_{t}=\left(x_{t}, \ldots, x_{m t}\right)^{\prime}$ are observable variables and $\mathrm{u}_{\mathrm{t}}$ indicates the error term. Equations (3) - (6) show level break (C), trend break (C/T), regime change $(\mathrm{C} / \mathrm{S})$ and regime change and trend break $(\mathrm{C} / \mathrm{T} / \mathrm{S})$, respectively. The null hypothesis for "no co-integration" is tested separately for the four models with the Maki (2012) cointegration test statistic. If the test statistic is greater than the critical value, the null hypothesis is rejected. In this case, it is decided that a long-run equilibrium relation between the variables is valid. Critical values are produced by Monte Carlo simulation.

The next step after the validation of the co-integration relation is to estimate the longrun coefficients that reveal the relationship between the variables. The DOLS developed by Stock and Watson (1993) is an appropriate and frequently used method for estimating co-integration coefficients. The DOLS method is a dynamic estimator that contains the lagged values of the differences of the independent variables. The DOLS estimator is defined in the following equation:

$\mathrm{y}_{\mathrm{t}}=\alpha_{0}+\alpha_{1} \mathrm{t}+\alpha_{2} \mathrm{x}_{\mathrm{t}}+\sum_{\mathrm{i}=-\mathrm{q}}^{\mathrm{q}} \delta_{\mathrm{i}} \Delta \mathrm{x}_{\mathrm{t}-\mathrm{i}}+\varepsilon_{\mathrm{t}}$

$\mathrm{Y}, \mathrm{t}, \mathrm{x}, \mathrm{q}, \Delta$, and $\varepsilon$ in Eq.(6) indicate the dependent variable, time period, independent variable, optimal lag, difference operator and the error term, respectively.

\section{Production of Financial Development Index for Turkey}

This study considers four key indicators to produce the FDI. The first is the deposit assets of the banks (Bank-assets). The second indicator is the total deposits of the financial system (Fin-deposits). The third is the broad money supply (Money) that represents the amount of money in circulation. The fourth indicator is the domestic 
credits provided in the private sector (Credit). FDI covers 1980-2013 period. Table 3 provides information for the indicators.

Table 3. Results of the PCA

\begin{tabular}{|c|c|c|c|c|c|}
\hline \multicolumn{6}{|l|}{ Eigenvalues } \\
\hline Number & Value & Difference & Proportion & $\begin{array}{c}\text { Cumulative } \\
\text { Value }\end{array}$ & $\begin{array}{l}\text { Cumulative } \\
\text { Proportion }\end{array}$ \\
\hline 1 & 3.692 & 3.446 & 0.923 & 3.692 & 0.923 \\
\hline 2 & 0.245 & 0.188 & 0.061 & 3.938 & 0.984 \\
\hline 3 & 0.057 & 0.053 & 0.014 & 3.995 & 0.998 \\
\hline 4 & 0.004 & - & 0.001 & 4.000 & 1.000 \\
\hline \multicolumn{6}{|l|}{ Eigenvectors } \\
\hline Variable & PC1 & PC2 & PC3 & PC4 & \\
\hline Bank-assets & 0.511 & -0.338 & -0.225 & 0.756 & \\
\hline Fin-deposits & 0.513 & 0.044 & -0.675 & -0.527 & \\
\hline Money & 0.499 & -0.470 & 0.630 & -0.361 & \\
\hline Credit & 0.474 & 0.813 & 0.308 & 0.134 & \\
\hline \multicolumn{6}{|c|}{ Correlation matrix } \\
\hline & $\begin{array}{l}\text { Bank- } \\
\text { assets }\end{array}$ & Fin-deposits & Money & Credit & \\
\hline Bank-assets & 1.000 & & & & \\
\hline Fin-deposits & 0.782 & 1.000 & & & \\
\hline Money & 0.900 & 0.711 & 1.000 & & \\
\hline Credit & 0.418 & 0.443 & 0.411 & 1.000 & \\
\hline
\end{tabular}

The PCA is followed in the production of the FDI. The purpose of this analysis is to transform a structure made up of several related variables into a single variable. During this transform, there is no significant loss of information about the structure (Abdi and Williams 2010). In the first step for the PCA, variables must have combinable properties. In other words, the units of the variables must be the same. Otherwise, variables are subject to transformation by standardization and rescaling methods. Thus, the differences between the units are eliminated. The unit of all variables used for the production of the FDI is the same (see Table 3). For this reason, PCA analysis is performed without any transformation. In the second step, the suitability of the data for the variables to PCA is investigated by Kaiser-Meyer-Olkin (KMO) and Bartlett (1950) tests. If the KMO test statistic is greater than 0.60, it indicates that the data set is suitable for analysis. The result of the KMO test statistic is calculated as 0.632. The sample adequacy measure statistics of Bank-assets, Fin-deposits, Credit and Money and 
variables are 0.627, 0.589, 0.725 and 0.628, respectively. The Bartlett test reveals whether there is a relationship between variables. Thus, it is decided whether the index production is suitable for the variables. The final decision is based on Bartlett test results and probability values (The test result should be statistically significant for PCA). The Bartlett test statistic and probability value results are estimated to be 21.008 and 0.000 , respectively.

In the third and final step of the PCA, the factors (eigenvalues) that explain the maximum variance between the variables are calculated. According to this calculation, the component whose eigenvalue is greater than 1 and the highest variance ratio (explanation proportion) is preferred. Once the most suitable component has been identified, the relevant index is produced using the weights of the variables. Table 3 depicts the PCA results. The first principal component (PC1) has an eigenvalue of 3.69 and a total variance ratio of $92 \%$. The $\mathrm{PC} 1$ component is more successful than the others. The first principal component (PC1) is selected and the weights of PC1 are used to produce the FDI for Turkey.

\section{Results and Discussion}

Table 4 provides preliminary information on descriptive statistics prior to econometric analysis. Descriptive statistics are not used to directly estimate model parameters but provide summary information about the data, showing the value trends and spreads of the data. For example, the mean, median, minimum, and maximum values of $\mathrm{Y}$ are greater than the values of other indicators. It is observed that the data used in the analysis have values close to each other. Finally, the standard errors of the data belonging to variables take values close to zero. These values indicate that the model estimation made with the indicators used in the analysis are effective.

Table 4. Descriptive statistics (1980 - 2013)

\begin{tabular}{lcccccc}
\hline Variables & Mean & Median & Maximum & Minimum & $\begin{array}{c}\text { Std. } \\
\text { Dev. }\end{array}$ & Observations \\
\hline INQ & -2.512 & -2.366 & -1.986 & -3.171 & 0.363 & 34 \\
Y & 8.947 & 8.946 & 9.462 & 8.515 & 0.263 & 34 \\
Trade & 3.654 & 3.737 & 4.006 & 2.838 & 0.271 & 34 \\
Modern & 3.402 & 3.407 & 3.526 & 3.170 & 0.185 & 34 \\
INF & 3.481 & 3.805 & 4.702 & 1.832 & 0.740 & 34 \\
Bank-assets & 3.232 & 3.134 & 3.919 & 2.467 & 0.397 & 34 \\
Fin-deposits & 3.389 & 3.182 & 4.313 & 2.884 & 0.442 & 34 \\
Money & 3.501 & 3.491 & 3.974 & 2.892 & 0.282 & 34 \\
Credit & 3.062 & 2.892 & 4.106 & 2.609 & 0.399 & 34 \\
FDI & 4.003 & 3.906 & 4.771 & 3.429 & 0.360 & 34 \\
\hline
\end{tabular}


Table 5 shows the ADF and PP unit root test results. The level values of the variables used in the analysis are not stationary. At least one of the test statistics reveals that the series contain unit roots. The first difference of the series is taken, and the unit root test is followed again. In this case, it is observed that all of the series are stationary in their first differences. All of the data used in the analysis is [I(1)]. For this reason, it is not possible to directly estimate the coefficients that reveal the relationship between variables. For the coefficient estimation, firstly the co-integration relation is investigated.

Table 5. Unit root tests

\begin{tabular}{|c|c|c|c|c|c|}
\hline \multirow[t]{2}{*}{ Variables } & & \multicolumn{2}{|c|}{ ADF test statistic } & \multicolumn{2}{|c|}{ PP test statistic } \\
\hline & & Intercept & $\begin{array}{c}\text { Intercept and } \\
\text { trend }\end{array}$ & Intercept & $\begin{array}{c}\text { Intercept and } \\
\text { trend }\end{array}$ \\
\hline INQ & & -1.340 & 0.090 & -1.452 & 0.020 \\
\hline $\mathrm{Y}$ & & 0.161 & -2.443 & 0.461 & -2.444 \\
\hline Trade & & -2.371 & $-4.169^{b}$ & $-3.140^{\mathrm{b}}$ & $-3.922^{\mathrm{b}}$ \\
\hline Modern & & -2.330 & -2.316 & $-3.142^{b}$ & -3.051 \\
\hline INF & & -0.268 & -1.606 & -0.974 & -1.151 \\
\hline Bank-assets & & -0.999 & -2.705 & -0.959 & -2.825 \\
\hline Fin-deposits & & 0.825 & -1.141 & 1.200 & -0.961 \\
\hline Money & & -0.983 & $-3.320^{\mathrm{c}}$ & -1.661 & $-4.633^{\mathrm{a}}$ \\
\hline Credit & & 0.459 & -0.458 & 0.282 & -0.615 \\
\hline FDI & & -0.063 & -1.631 & 0.257 & -1.152 \\
\hline$\Delta \mathrm{INQ}$ & & $-5.038^{\mathrm{a}}$ & $-6.006^{\mathrm{a}}$ & $-5.146^{\mathrm{a}}$ & $-5.986^{\mathrm{a}}$ \\
\hline$\Delta \mathrm{Y}$ & & $-5.928^{\mathrm{a}}$ & $-5.890^{\mathrm{a}}$ & $-5.954^{\mathrm{a}}$ & $-5.918^{\mathrm{a}}$ \\
\hline$\Delta$ Trade & & $-4.870^{\mathrm{a}}$ & $-5.024^{\mathrm{a}}$ & $-4.872^{\mathrm{a}}$ & $-4.991^{\mathrm{a}}$ \\
\hline$\Delta$ Modern & & $-4.809^{\mathrm{a}}$ & $-4.718^{a}$ & $-5.376^{\mathrm{a}}$ & $-5.190^{\mathrm{a}}$ \\
\hline$\Delta \mathrm{INF}$ & & $-4.068^{\mathrm{a}}$ & $-4.416^{\mathrm{a}}$ & $-6.260^{\mathrm{a}}$ & $-6.608^{a}$ \\
\hline$\Delta$ Bank-assets & & $-5.488^{\mathrm{a}}$ & $-5.420^{\mathrm{a}}$ & $-5.657^{\mathrm{a}}$ & $-5.532^{\mathrm{a}}$ \\
\hline$\Delta$ Fin-deposits & & $-4.599^{\mathrm{a}}$ & $-5.541^{\mathrm{a}}$ & $-5.453^{\mathrm{a}}$ & $-5.842^{\mathrm{a}}$ \\
\hline$\Delta$ Money & & $-5.241^{\mathrm{a}}$ & $-5.139^{\mathrm{a}}$ & $-9.319^{\mathrm{a}}$ & $-9.098^{\mathrm{a}}$ \\
\hline$\Delta$ Credit & & $-3.962^{\mathrm{a}}$ & $-4.530^{\mathrm{a}}$ & $-4.316^{\mathrm{a}}$ & $-4.656^{\mathrm{a}}$ \\
\hline$\Delta \mathrm{FDI}$ & & $-4.904^{\mathrm{a}}$ & $-5.312^{\mathrm{a}}$ & $-6.275^{\mathrm{a}}$ & $-6.650^{\mathrm{a}}$ \\
\hline \multirow[t]{3}{*}{ Critical values } & $1 \%$ & $-3,646$ & -4.262 & $-3,646$ & -4.262 \\
\hline & $5 \%$ & $-2,954$ & -3.552 & $-2,954$ & -3.552 \\
\hline & $10 \%$ & $-2,615$ & -3.209 & $-2,615$ & -3.209 \\
\hline
\end{tabular}

Notes: (1) ${ }^{a},{ }^{b c}$ indicate the rejection of the null hypothesis at 1, 5, and $10 \%$ levels of significance, respectively. 
Table 6 exhibits the result of the structural breaks co-integration test. Maki (2012) level break (equation 3) co-integration test results are reported. Models from 1 to 5 reveal the co-integration relationship between income inequality, economic growth, trade, modernization, inflation and financial development (linear models). Model 6 refers to the co-integration relationship between income inequality, economic growth, trade, modernization, inflation, financial development and the square of financial development (nonlinear model). The co-integration test results for all models support the long-term equilibrium relationship between variables. All models are co-integrated. The breaking dates indicated by the co-integration test results are 1982, 1985, 1988, 1989, 1991, 1994, 2007, and 2011. Turkey has experienced a military coup in the early 1980s. Democracy was over, and there was political instability. On the other hand, it began a liberalization process in Turkey over the same period. In particular, Turkey has made significant progress in liberalization at the end of the 1980s. Similarly, periods 1991 and 1994 correspond to periods before and after the economic crisis in 1993. Finally, periods 2007 and 2011 indicate the periods of the global financial crisis. These structural changes or breaks experienced during this period have an increasing or decreasing effect on many economic variables. For this reason, the break dates obtained from the co-integration test results are included as an additional explanatory variable to the regression model. Thus, the effect of the structural changes in the relevant dates on the dependent variable is explained.

Table 6. Co-integration results

\begin{tabular}{|c|c|c|c|}
\hline Co-integration Models & $\begin{array}{c}\text { Test } \\
\text { statistic }\end{array}$ & $\begin{array}{c}\text { Break } \\
\text { dates }\end{array}$ & Decision \\
\hline $\begin{array}{l}\text { Model (1) } \\
\text { INQ = f (Y, Trade, Modern, INF, Bank-assets) }\end{array}$ & $-6.111^{b}$ & $\begin{array}{l}1982 \\
1989\end{array}$ & Co-integrated \\
\hline $\begin{array}{l}\text { Model (2) } \\
\text { INQ = f (Y, Trade, Modern, INF, Fin-deposits) }\end{array}$ & $-5.871^{\mathrm{b}}$ & $\begin{array}{c}1985 \\
1988\end{array}$ & Co-integrated \\
\hline $\begin{array}{l}\text { Model (3) } \\
\text { INQ = f (Y, Trade, Modern, INF, Money) }\end{array}$ & $-5.942^{b}$ & $\begin{array}{l}1989 \\
1994\end{array}$ & Co-integrated \\
\hline $\begin{array}{l}\text { Model (4) } \\
\text { INQ = f (Y, Trade, Modern, INF, Credit) }\end{array}$ & $-6.046^{\mathrm{b}}$ & $\begin{array}{l}1989 \\
2011\end{array}$ & Co-integrated \\
\hline $\begin{array}{l}\text { Model (5) } \\
\text { INQ = f (Y, Trade, Modern, INF, FDI) }\end{array}$ & $-5,863^{\mathrm{b}}$ & $\begin{array}{l}1994 \\
2007\end{array}$ & Co-integrated \\
\hline $\begin{array}{l}\text { Model (6) } \\
\left.\text { INQ = f (Y, Trade, Modern, INF, FDI, FDI }{ }^{2}\right)\end{array}$ & $-7,215^{a}$ & $\begin{array}{c}1988 \\
1991\end{array}$ & Co-integrated \\
\hline
\end{tabular}


The next step in determining the co-integration relationship is to estimate the long-run co-integration coefficients that explain the relationship between variables. Table 7 shows the results of long-run parameters estimates. These results are obtained by Stock and Watson (1993) DOLS estimators.

Table 7. Estimation of the long-term coefficients (Baseline results)

\begin{tabular}{|c|c|c|c|c|c|c|}
\hline $\begin{array}{l}\text { Independent } \\
\text { variables }\end{array}$ & $\begin{array}{c}\text { Model } \\
\text { (1) }\end{array}$ & $\begin{array}{l}\text { Model } \\
\text { (2) }\end{array}$ & $\begin{array}{c}\text { Model } \\
\text { (3) }\end{array}$ & $\begin{array}{c}\text { Model } \\
\text { (4) }\end{array}$ & $\begin{array}{l}\text { Model } \\
\text { (5) }\end{array}$ & $\begin{array}{c}\text { Model } \\
\text { (6) }\end{array}$ \\
\hline $\mathrm{Y}$ & $\begin{array}{l}-2.361^{\mathrm{a}} \\
(0.005)\end{array}$ & $\begin{array}{l}-2.224^{\mathrm{a}} \\
(0.000)\end{array}$ & $\begin{array}{l}-2.005^{\mathrm{b}} \\
(0.013)\end{array}$ & $\begin{array}{l}-2.169^{\mathrm{a}} \\
(0.007)\end{array}$ & $\begin{array}{l}-1.839^{\mathrm{b}} \\
(0.020)\end{array}$ & $\begin{array}{l}2.083^{\mathrm{c}} \\
(0.068)\end{array}$ \\
\hline Trade & $\begin{array}{c}0.356 \\
(0.120)\end{array}$ & $\begin{array}{c}0.003 \\
(0.988)\end{array}$ & $\begin{array}{c}0.340 \\
(0.160)\end{array}$ & $\begin{array}{l}-0.479 \\
(0.187)\end{array}$ & $\begin{array}{c}0.282 \\
(0.256)\end{array}$ & $\begin{array}{c}0.048 \\
(0.906)\end{array}$ \\
\hline Modern & $\begin{array}{l}-0.164 \\
(0.757)\end{array}$ & $\begin{array}{l}-4.080^{\mathrm{a}} \\
(0.001)\end{array}$ & $\begin{array}{c}0.209 \\
(0.683)\end{array}$ & $\begin{array}{l}-0.915 \\
(0.198)\end{array}$ & $\begin{array}{c}0.214 \\
(0.658)\end{array}$ & $\begin{array}{l}-0.801 \\
(0.274)\end{array}$ \\
\hline INF & $\begin{array}{l}0.005^{c} \\
(0.089)\end{array}$ & $\begin{array}{l}0.097^{\mathrm{c}} \\
(0.069)\end{array}$ & $\begin{array}{l}-0.044 \\
(0.946)\end{array}$ & $\begin{array}{c}0.275^{\mathrm{b}} \\
(0.013)\end{array}$ & $\begin{array}{c}0.031 \\
(0.636)\end{array}$ & $\begin{array}{l}0.204^{\mathrm{b}} \\
(0.037)\end{array}$ \\
\hline Bank-assets & $\begin{array}{l}-1.006^{\mathrm{b}} \\
(0.016)\end{array}$ & & & & & \\
\hline Fin-deposits & & $\begin{array}{l}-1.175^{\mathrm{a}} \\
(0.000)\end{array}$ & & & & \\
\hline Money & & & $\begin{array}{l}-0.722^{b} \\
(0.037)\end{array}$ & & & \\
\hline Credit & & & & $\begin{array}{l}-0.556^{\mathrm{a}} \\
(0.005)\end{array}$ & & \\
\hline FDI & & & & & $\begin{array}{l}-1.493^{\mathrm{a}} \\
(0.000)\end{array}$ & $\begin{array}{l}10.649^{c} \\
(0.059)\end{array}$ \\
\hline $\mathrm{FDI}^{2}$ & & & & & & $\begin{array}{l}-1.444^{b} \\
(0.038)\end{array}$ \\
\hline Dummy 1 & $\begin{array}{c}0.158 \\
(0.418)\end{array}$ & $\begin{array}{l}0.531^{\mathrm{a}} \\
(0.000)\end{array}$ & $\begin{array}{l}0.539^{\mathrm{a}} \\
(0.001)\end{array}$ & $\begin{array}{c}0.242 \\
(0.101)\end{array}$ & $\begin{array}{c}0.004 \\
(0.977)\end{array}$ & $\begin{array}{c}0.257 \\
(0.220)\end{array}$ \\
\hline Dummy 2 & $\begin{array}{l}0.364^{\mathrm{b}} \\
(0.026)\end{array}$ & $\begin{array}{l}0.321^{\mathrm{c}} \\
(0.061)\end{array}$ & $\begin{array}{c}0.181 \\
(0.202)\end{array}$ & $\begin{array}{l}-0.152 \\
(0.334)\end{array}$ & $\begin{array}{c}0.034 \\
(0.838)\end{array}$ & $\begin{array}{c}0.388 \\
(0.190)\end{array}$ \\
\hline Constant & $\begin{array}{l}19.004 \mathrm{a} \\
(0.005)\end{array}$ & $\begin{array}{l}-5.583 \\
(0.197)\end{array}$ & $\begin{array}{l}14.943^{\mathrm{b}} \\
(0.023)\end{array}$ & $\begin{array}{c}-16.498^{a} \\
(0.003)\end{array}$ & $\begin{array}{l}15.930^{\mathrm{b}} \\
(0.012)\end{array}$ & $\begin{array}{l}-38.803^{\mathrm{a}} \\
(0.002)\end{array}$ \\
\hline Adj. $R^{2}$ & 0.872 & 0.928 & 0.873 & 0.915 & 0.874 & 0.746 \\
\hline
\end{tabular}

Notes: (1) ${ }^{a},{ }^{b c}$, indicate significance at the $1 \%, 5 \%$, and $10 \%$, respectively.

(2) Dependent variable: INQ.

(3) The optimal lag length for all models is 1. 
Estimation results are as follows:

(1) The parameter of deposit assets (Bank-assets) of the banks is negative and 5\% statistically significant (see model 1). An increase in banks' deposit assets has a mitigating or improving effect on income inequality. (2) The parameter of total deposits of the financial system (Fin- deposits) is negative and 1\% statistically significant (see model 2). An increase in the total deposits of the financial system has a mitigating effect on income inequality. (3) The parameter of broad money supply (Money) is negative and 5\% statistically significant (see model 3). An increase in the money supply reduces income inequality. (4) The parameter of the domestic credits provided in the private sector (Credit) is negative and $1 \%$ statistically significant (see model 4 ). This finding suggests that the increase in domestic credits is a mitigating effect on income inequality. (5) The parameter of the financial development index (FDI) obtained from the aggregation of the financial development indicators is negative and $1 \%$ statistically significant (see model 5). When all linear models are evaluated, strong findings are observed that financial development is a mitigating effect on income inequality. The estimation results of the linear models support the inequality-narrowing hypothesis. Model 6 estimates the non-linear relationship between financial development and income inequality. The parameters for financial development and the square of financial development are respectively positive and negative. Both coefficients are statistically significant at 5\%. This finding suggests that financial development has an increasing impact on income inequality. However, once the financial structure reaches a certain level of development, this effect reverses and financial development has a decreasing impact on income inequality. In other words, the estimation results of model 6 support the Greenwood-Jovanovic hypothesis.

Economic growth (Y) has a significant and strong negative impact on income inequality. Economic growth has a strong mitigating effect on income inequality (The parameter of economic growth is negative for all other models except Model 6). The parameter of trade openness (Trade) is statistically insignificant in all models. The effect of modernization on income inequality is weak. According to the estimation results of the second model only, the parameter of modernization (Modern) is negative and significant. The neutrality hypothesis is supported by other models. According to economic expectations, inflation is a factor that increases income inequality. When the estimation results are evaluated, the parameters of the inflation (INF) are positive and significant (for four models). Findings related to inflation support economic expectations. The estimation results of the parameters of the dummy variables are mixed. The parameters of dummy variables representing 1985, 1988 and 1989 are positive and significant. This implies that the liberalization process at the end of the 1980 s and military coup is an increasing effect on income inequality.

Finally, analysis is repeated with an alternative estimator to robustness check. The fully modified least squares (FM-OLS) regression analysis method developed by Philips and Hansen (1990) is used for robustness check. The method modifies the OLS method by considering serial correlation effects and endogeneity in the regressors. Thus, the FM- 
OLS estimator produces more reliable results in co-integration parameters. Table 8 reports FM-OLS estimation results. The FM-OLS results for all of the linear models strongly suggest that financial development is a mitigating effect of income inequality. The FMOLS estimation results of the linear models support the validity of the inequality-narrowing hypothesis. Alternative estimation results of Model 6, which reveal non-linear relationship between financial development and income inequality, are similar to baseline results. When the parameter estimation results of model 6 are evaluated, it is seen that the Greenwood-Jovanovic hypothesis is supported.

Table 8. Robustness check (Alternative estimator)

\begin{tabular}{lcccccc}
\hline $\begin{array}{l}\text { Independent } \\
\text { variables }\end{array}$ & $\begin{array}{c}\text { Model } \\
(\mathbf{1})\end{array}$ & $\begin{array}{c}\text { Model } \\
\mathbf{( 2 )}\end{array}$ & $\begin{array}{c}\text { Model } \\
\mathbf{( 3 )}\end{array}$ & $\begin{array}{c}\text { Model } \\
\mathbf{( 4 )}\end{array}$ & $\begin{array}{c}\text { Model } \\
(\mathbf{5})\end{array}$ & $\begin{array}{c}\text { Model } \\
(\mathbf{6})\end{array}$ \\
\hline $\mathrm{Y}$ & $-3.177^{\mathrm{a}}$ & $-1.888^{\mathrm{a}}$ & $-2.586^{\mathrm{a}}$ & $-0.361^{\mathrm{b}}$ & $-1.791^{\mathrm{a}}$ & 2.114 \\
& $(0.000)$ & $(0.000)$ & $(0.003)$ & $(0.030)$ & $(0.006)$ & $(0.100)$ \\
\hline Trade & $0.648^{\mathrm{c}}$ & 0.107 & $0.555^{\mathrm{c}}$ & 0.580 & 0.240 & 0.068 \\
& $(0.094)$ & $(0.340)$ & $(0.065)$ & $(0.911)$ & $(0.275)$ & $(0.845)$ \\
\hline Modern & 0.220 & $-0.802^{\mathrm{b}}$ & 0.469 & -0.270 & 0.177 & -0.531 \\
& $(0.717)$ & $(0.018)$ & $(0.340)$ & $(0.450)$ & $(0.687)$ & $(0.386)$ \\
\hline INF & 0.087 & $0.084^{\mathrm{b}}$ & -0.006 & 0.057 & $0.033^{\mathrm{c}}$ & $0.216^{\mathrm{a}}$ \\
& $(0.286)$ & $(0.013)$ & $(0.402)$ & $(0.147)$ & $(0.059)$ & $(0.000)$ \\
\hline
\end{tabular}

\begin{tabular}{|c|c|c|c|c|c|c|}
\hline Bank-assets & $\begin{array}{l}-1.271^{\mathrm{a}} \\
(0.002)\end{array}$ & & & & & \\
\hline Fin-deposits & & $\begin{array}{l}-1.269^{\mathrm{a}} \\
(0.000)\end{array}$ & & & & \\
\hline Money & & & $\begin{array}{l}-0.889^{\mathrm{a}} \\
(0.009)\end{array}$ & & & \\
\hline Credit & & & & $\begin{array}{l}-0.272^{\mathrm{a}} \\
(0.007)\end{array}$ & & \\
\hline FDI & & & & & $\begin{array}{l}-1.604^{\mathrm{a}} \\
(0.000)\end{array}$ & $\begin{array}{l}11.036^{\mathrm{a}} \\
(0.009)\end{array}$ \\
\hline $\mathrm{FDI}^{2}$ & & & & & & $\begin{array}{c}-1.499^{\mathrm{a}} \\
(0.004) \\
\end{array}$ \\
\hline Dummy 1 & $\begin{array}{c}0.238 \\
(0.220)\end{array}$ & $\begin{array}{c}0.136^{\mathrm{b}} \\
(0.036)\end{array}$ & $\begin{array}{c}0.551^{\mathrm{a}} \\
(0.002)\end{array}$ & $\begin{array}{c}0.765^{\mathrm{a}} \\
(0.000)\end{array}$ & $\begin{array}{c}0.001 \\
(0.990)\end{array}$ & $\begin{array}{c}0.282^{\mathrm{c}} \\
(0.060)\end{array}$ \\
\hline Dummy 2 & $\begin{array}{l}0.392^{\mathrm{b}} \\
(0.025)\end{array}$ & $\begin{array}{c}0.201^{\mathrm{a}} \\
(0.009)\end{array}$ & $\begin{array}{c}0.173 \\
(0.207)\end{array}$ & $\begin{array}{l}-0.175^{\mathrm{c}} \\
(0.065)\end{array}$ & $\begin{array}{c}0.090 \\
(0.402)\end{array}$ & $\begin{array}{c}0.423^{\mathrm{c}} \\
(0.055)\end{array}$ \\
\hline Constant & $\begin{array}{l}14.701^{\mathrm{a}} \\
(0.005)\end{array}$ & $\begin{array}{l}19.292^{\mathrm{a}} \\
(0.000)\end{array}$ & $\begin{array}{l}18.672^{\mathrm{a}} \\
(0.004)\end{array}$ & $\begin{array}{c}-14.378^{a} \\
(0.000)\end{array}$ & $\begin{array}{l}16.410^{\mathrm{a}} \\
(0.001)\end{array}$ & $\begin{array}{c}-40.771^{\mathrm{a}} \\
(0.000)\end{array}$ \\
\hline Adj. $R^{2}$ & 0.856 & 0.931 & 0.857 & 0.888 & 0.859 & 0.718 \\
\hline
\end{tabular}

Notes: (1) ${ }^{a}, b^{b}$, . indicate significance at the $1 \%, 5 \%$, and $10 \%$, respectively.

(2) Dependent variable: INQ. (3) The optimal lag length for all models is 1. 
The empirical findings of this paper are discussed from three perspectives for potential readers and policy authorities. First, the linear model estimation results for Turkey support the inequality-narrowing hypothesis. These findings are similar to the results of Beck et al. (2004), Ang (2010), Bittencourt (2010), Kappel (2010), Mookerjee and Kalipioni (2010), Jalil and Feridun (2011), Kim and Lin (2011), Prete (2013) and Tiwari et al. (2013). These findings indicate that the increase in assets in the banking system, the growth of domestic credit, and the expansion of money supply have a decreasing effect on income inequality in Turkey. Therefore, incentives and policies towards financial developments in Turkey are expected to contribute to the fight against income inequality. Second, the estimation findings for the nonlinear model confirm the Greenwood-Jovanovic hypothesis. These results are similar to previous findings obtained by Shahbaz et al. (2015), Azam and Ali Raza (2018), Younsi and Bechtini (2018) and Bittencourt et al. (2018). These results indicate that financial development increases income inequality in the short term or up to certain point but decreases in the long term or after a certain point.

After all, this paper reveals an inverse U-shaped relationship between financial development and income inequality in Turkey. It also shows that the final impact of financial development on income inequality is mitigating. Third, we discuss the possible reasons for the results obtained for Turkey. A possible reason behind this conclusion is the fact that low-income groups in society can access credit facilities as a result of the developments in the financial system. Thus, the poor can obtain the necessary funds for human and physical capital investment. Supports the outputs o this paper, credits have been an important policy variable since the second half of 2010 in Turkey. Authorities have followed policies that support credit growth by taking into account global liquidity conditions (Aydın and Y1lmaz, 2019). As a result of these policies, while the credit / GDP ratio was $18 \%$ in 1998, the credit / GDP ratio reached $40 \%$ in 2010 and $65 \%$ in 2017 (Central Bank of the Republic of Turkey, 2019). During the same periods, similar growth tendencies are observed in monetary expansion and banks' assets. Thus, in recent years in Turkey have experienced liquidity and credit expansion and interest rates have remained at relatively low levels. These developments may have enabled lowincome groups in the country to access loans and move to a better income level.

\section{Conclusion}

This paper examines the linear and nonlinear effects of financial development on income inequality in Turkey over the period of 1980-2013. Indicators of financial development are deposits, money assets of banks, deposits of the financial system, domestic credits, and broad money supply. In addition, these four indicators are aggregated, and a financial development index is produced by the PCA method. Economic growth, trade, inflation, and modernization are added to the regression model as control variables. Structural breaks co-integration test and DOLS estimator are used for empirical investigation. Robustness check is performed with the FM-OLS estimator. According to the estimation results of linear relationship, financial development has a mitigating effect on income inequality. These results are consistent with the literature supporting the inequality-narrowing hypothesis. The estimation results of the nonlinear relationship show that financial development first increases income inequality, but after 
financial development reaches a certain level, this effect is reversed, and financial development reduces income inequality. These results are in line with the literature supporting the Greenwood-Jovanovic hypothesis. Empirical results for all models strongly suggest that financial development is a mitigating or improving effect on income inequality over the long-run. Finally, empirical analysis reveals that economic growth and inflation are also significant influences on income inequality. Another remarkable result is that economic growth and inflation are also significant influences on income inequality.

Within the framework of empirical findings in Turkey, it is recommended that the following direct policies be followed (Law and Tan 2009; Suter 2010; Shahbaz and Islam 2011; Law et al. 2014; Ahmed and Masih 2017; Kaidi et al. 2018): (a) Policymakers should take measures to reduce constraints and disruptions in the financial markets when designing policies to combat poverty and economic growth. (b) A financial environment should be created to enable the poor to reach a better life opportunity. For this, regulations that make financial resources difficult to access should be audited and access to capital should be facilitated. Thus, entrepreneurial activities may develop and productivity increases throughout the economy. Moreover, lowincome individuals make the necessary investments in their education. Among lowincome people, skilled labor is emerging in engineering, medicine, and other fields. (c) Policies and incentives to support the development of private credit channels can help reduce income inequality. Indirect policies to be followed are: (d) Factors such as bureaucracy, disruptions in the legal system, high transaction costs and an insecure business environment make access to finance difficult. Governments must first provide the necessary institutional environment to improve income distribution and combat poverty. (e) Finally, policies that encourage economic growth also cause a reduction in income inequality. Macroeconomic stability is also critical to combat income inequality. In particular, the fight against inflation provides a significant improvement in income inequality.

Disclosure statement: The authors reported no potential conflict of interest.

\section{References}

ABDI, H., WILLIAMS, L. J. (2010), Principal component analysis, Wiley Interdisciplinary Reviews: Computational Statistics, 2(4), 433-459. DOI: 10.1002/wics.101

ABOSEDRA, S., SHAHBAZ, M., NAWAZ, K. (2016). Modeling causality between financial deepening and poverty reduction in Egypt. Social Indicators Research, 126(3), 955-969. DOI: $\underline{10.1007 / \mathrm{s} 11205-015-0929-2}$

AHMAD, N., DU, L., Lu, J., WANG, J., Li, H. Z., HASHMI, M. Z. (2017). Modelling the $\mathrm{CO} 2$ emissions and economic growth in Croatia: Is there any environmental Kuznets curve?. Energy, 123, 164-172. DOI: 10.1016/j.energy.2016.12.106

AHMED, A. R., MASIH, M. (2017). What is the link between financial development and income inequality? evidence from Malaysia. MPRA Paper No. 79416. 
AKINBOADE, O. A., INFACK, E. C. (2014). Financial sector development indicators and economic growth in Cameroon and South Africa. Social indicators research, 115(2), 813-836. DOI: $10.1007 / \mathrm{s} 11205-013-0236-8$

AL-AZZAM, A., \& HAWDON, D. (1999). Estimating the demand for energy in Jordan: a Stock-Watson dynamic OLS (DOLS) approach (No. 97). Surrey Energy Economics Centre (SEEC), School of Economics, University of Surrey.

ANG, J. B. (2010). Finance and inequality: the case of India. Southern economic journal, 76(3), 738-761.

AZAM, M., RAZA, S. A. (2018). Financial sector development and income inequality in ASEAN-5 countries: does financial Kuznets curve exists?. Global Business and Economics Review, 20(1), 88-114. DOI: 10.1504/GBER.2018.088482

AYDIN, H. I., YILMAZ, G. (2019). Türk Bankacilik Sektörü için Kredi Açigi Göstergeleri (No. 1902). Research and Monetary Policy Department, Central Bank of the Republic of Turkey.

BANERJEE, A. V., NEWMAN, A. F. (1993). Occupational choice and the process of development. Journal of political economy, 101(2), 274-298. DOI: $\underline{10.1086 / 261876}$

BARTLETT, M. S. (1950). Tests of significance in factor analysis. British Journal of Statistical Psychology, 3(2), 77-85. DOI: 10.1111/j.2044-8317.1950.tb00285.x

BATUO, M. E., GUIDI, F., MLAMBO, K. (2010). Financial development and income inequality: Evidence from African Countries. MPRA Paper No. 25658.

BECK, T., DEMIRGÜÇ-KUNT, A., LEVINE, R. (2000). A New Database on Financial Development and Structure. World Bank Economic Review 14, 597-605. DOI: $\underline{10.1093 / w b e r / 14.3 .597}$

BECK, T., DEMIRGUC-KUNT, A., LEVINE, R. (2004). Finance, inequality, and poverty: Cross-country evidence (No. w10979). National Bureau of Economic Research.

BECK, T., DEMIRGÜÇ-KUNT, A., \& LEVINE, R. (2009). Financial institutions and markets across countries and over time-data and analysis. World Bank Policy Research Working Paper 4943.

BITTENCOURT, M. (2010). Financial development and inequality: Brazil 1985-1994. Economic Change and Restructuring, 43(2), 113-130.

BITTENCOURT, M., CHANG, S., GUPTA, R., MILlER, S. M. (2018). Does Financial Development Affect Income Inequality in the US States? A Panel Data Analysis (No. 201803).

Central Bank of the Republic of Turkey (2019). Statistical Database.

ČIHÁK, M., DEMIRGÜÇ-KUNT, A., FEYEN, E., LEVINE, R. (2012). Benchmarking financial systems around the world. Policy Research Working Paper 6175.

CLARKE, G. R., XU, L. C., ZOU, H. F. (2006). Finance and income inequality: what do the data tell us?. Southern economic journal, 578-596. 
DE HAAN, J., STURM, J. E. (2017). Finance and income inequality: A review and new evidence. European Journal of Political Economy, 50, 171-195. DOI: 10.1016/j.ejpoleco.2017.04.007

DICKEY, D. A., FULLER, W. A. (1981). Likelihood Ratio Statistics for Autoregressive Time Series with A Unit Root. Econometrica: Journal of the Econometric Society, 1057-1072. DOI: 10.2307/1912517

ENGLE, R. F., GRANGER, C. W. J. (1987). Co-integration and Error Correction: Representation, Estimation, and Testing. Econometrica: Journal of the Econometric Society, 251-276. DOI: $10.2307 / 1913236$

GALOR, O., ZEIRA, J. (1993). Income distribution and macroeconomics. The review of economic studies, 60(1), 35-52.

GREENWOOD, J., JOVANOVIC, B. (1990). Financial development, growth, and the distribution of income. Journal of political Economy, 98(5, Part 1), 1076-1107. DOI: $10.1086 / 261720$

GREGORY, A. W., HANSEN, B. E. (1996). Residual-based Tests for Cointegration in Models with Regime Shifts. Journal of Econometrics, 70(1), 99-126. DOI: $\underline{10.1016 / 0304-4076(69) 41685-7}$

HATEMI-J, A. (2008). Tests for Cointegration with Two Unknown Regime Shifts with An Application to Financial Market Integration. Empirical Economics, 35(3), 497-505. DOI: $\underline{10.1007 / \mathrm{s} 00181-007-0175-9}$

FOWOWE, B., ABIDOYE, B. (2013). The effect of financial development on poverty and inequality in African countries. The Manchester School, 81(4), 562-585. DOI: $\underline{10.1111 / \mathrm{j} .1467-9957.2012 .02302 . \mathrm{x}}$

IRFFI, G., CASTELAR, I., SIQUEIRA, M., LINHARES, F. (2008). Dynamic OLS and regime switching models to forecast the demand for electricity in the northeast of Brazil. Downloaded fromhttp://epge. fgv. br/finrio/myreview/FILES/CR2/p44. pdf. Date of access: February 12, 2018.

JALIL, A., \& FERIDUN, M. (2011). Long-run relationship between income inequality and financial development in China. Journal of the Asia Pacific Economy, 16(2), 202214. DOI: $10.1080 / 13547860.2011 .564745$

JOHANSEN, S. (1988). Statistical Analysis of Cointegration Vectors. Journal of Economic Dynamics and Control, 12 (2), 231-254. DOI: 10.1016/01651889(88)90041-3

JOHANSEN, S., JUSELIUS, K. (1990). Maximum Likelihood Estimation and Inference on Cointegration-with Applications to the Demand for Money. Oxford Bulletin of Economics and Statistics, 52 (2), 169-210. DOI: 10.1111/j.14680084.1990.mp52002003.X

KAIDI, N., MENSI, S., AMOR, M. B. (2018). Financial Development, Institutional Quality and Poverty Reduction: Worldwide Evidence. Social Indicators Research, 1-26. 
KAISER, H. F. (1974). An index of factorial simplicity. Psychometrika, 39(1), 31-36. DOI: $10.1007 / \mathrm{BF} 02291575$

KAPPEL, V. (2010) : The effects of financial development on income inequality and poverty, Proceedings of the German Development Economics Conference, Hannover 2010, No. 25

KIM, D. H., LIN, S. C. (2011). Nonlinearity in the financial development-income inequality nexus. Journal of Comparative Economics, 39(3), 310-325. DOI: 10.1016/j.jce.2011.07.002

KOÇAK, E., ŞARKGÜNEŞI, A. (2018). The impact of foreign direct investment on $\mathrm{CO} 2$ emissions in Turkey: new evidence from cointegration and bootstrap causality analysis. Environmental Science and Pollution Research, 25(1), 790-804. DOI: 10.1007/s11356-017-0468-2

KUNIEDA, T., OKADA, K., SHIBATA, A. (2014). Finance and inequality: How does Kuznets, S. (1955). Economic growth and income inequality. The American economic review, 45 (1), 1-28.

LAW, S. H., TAN, H. B. (2009). The role of financial development on income inequality in Malaysia. Journal of Economic Development, 34(2), 153-168. DOI: 10.35866/caujed.2009.34.2.008

LAW, S. H., TAN, H. B., Azman-Saini, W. N. W. (2014). Financial development and income inequality at different levels of institutional quality. Emerging Markets Finance and Trade, 50(sup1), 21-33.

LEE, C. C., LEE, C. C. (2018). The Impact of Country Risk on Income Inequality: A Multilevel Analysis. Social Indicators Research, 136(1), 139-162. DOI: $\underline{10.1007 / \mathrm{s} 11205-016-1534-8}$

LEVINE, R. (2005). Finance and growth: theory and evidence. Handbook of economic growth, 1, 865-934. DOI: 10.1016/S1574-0684(05)01012-9

LIANG, Z. (2008). Financial development and income inequality in rural China 19912000. In Understanding Inequality and Poverty in China (pp. 72-88). Palgrave Macmillan, London.

LING-ZHENG, Y. U., XIA-HAI, W. E. I. (2012). Has financial development worsened income inequality in China? Evidence from threshold regression model. Journal of Finance and Economics, CNKI: SUN:CJYJ.0.2012-03-009.

MAKI, D. (2012). Tests for cointegration allowing for an unknown number of breaks. Economic Modelling, 29(5), 2011-2015. DOI: 10.1016/j.econmod.2012.04.022

MASIH, R., \& MASIH, A. M. (1996). Stock-Watson dynamic OLS (DOLS) and errorcorrection modelling approaches to estimating long-and short-run elasticities in a demand function: new evidence and methodological implications from an application to the demand for coal in mainland China. Energy Economics, 18(4), 315-334. DOI: 10.1016/S0140-9883(96)00016-3 
MONTALVO, J. G. (1995). Comparing cointegrating regression estimators: Some additional Monte Carlo results. Economics letters, 48(3-4), 229-234.

MOOKERJEE, R., KALIPIONI, P. (2010). Availability of financial services and income inequality: The evidence from many countries. Emerging Markets Review, 11(4), 404-408. DOI: 10.1016/j.ememar.2010.07.001

PARDO, G. P., SÁNCHEZ SANTOS, J. M. (2014). Household debt and consumption inequality: The Spanish case. Economies, 2(3), 147-170. DOI: $\underline{10.3390 / \text { economies } 2030147}$

PESARAN, M. H., SHIN, Y., SMITH, R. J. (2001). Bounds testing approaches to the analysis of level relationships. Journal of applied econometrics, 16(3), 289-326. DOI: $\underline{10.1002 / j a e .616}$

PHILLIPS, P. C., HANSEN, B. E. (1990). Statistical Inference in Instrumental Variables Regression with I (1) Processes. The Review of Economic Studies, 57(1), 99125.

PHILliPS, P. C., PERRON, P. (1988). Testing for A Unit Root in Time Series Regression. Biometrika, 75(2), 335-346. DOI: 10.1093/biomet/75.2.335

PRETE, A. L. (2013). Economic literacy, inequality, and financial development. Economics Letters, 118(1), 74-76. DOI: 10.1016/j.econlet.2012.09.029

SATTI, S. L., MAHALIK, M. K., BHATTACHARYA, M., SHAHBAZ, M. (2015). Dynamics of Income Inequality, Finance and Trade in Kazakhstan: Empirical Evidence from a New Transition Economy with Policy Prescriptions. Monash Business School, Department of Economics Discussion Paper, No. 36/15.

SEHRAWAT, M., GIRI, A. K. (2016). Financial development, poverty and rural-urban income inequality: evidence from South Asian countries. Quality \& Quantity, 50(2), 577-590. DOI: 10.1007/s11135-015-0164-6

SHAHBAZ, M. (2010). Income inequality-economic growth and non-linearity: a case of Pakistan. International Journal of Social Economics, 37(8), 613-636. DOI: $\underline{10.1108 / 03068291011060652}$

SHAHBAZ, M., ISLAM, F. (2011). Financial development and income inequality in Pakistan: an application of ARDL approach. Journal of economic development, 36(1), 35-58. DOI: 10.35866/caujed.2011.36.1.003

SHAHBAZ, M., LOGANATHAN, N., TIWARI, A. K., SHERAFATIAN-JAHROMI, R. (2015). Financial development and income inequality: is there any financial Kuznets curve in Iran?. Social Indicators Research, 124(2), 357-382. DOI: 10.1007/s11205014-0801-9

SOLT, F. (2009). Standardizing the world income inequality database. Social Science Quarterly, 90(2), 231-242. DOI: 10.1111/j.1540-6237.2009.00614.x 
STOCK, J. H., WATSON, M. W. (1993). A Simple Estimator of Cointegrating Vectors in Higher Order Integrated Systems. Econometrica: Journal of the Econometric Society, 61(4), 783-820. DOI: $10.2307 / 2951763$

SUTER, C. (2009). Inequality beyond Globalization: Searching for the Missing Pieces of the Puzzle: Introduction to Special Issue. International Journal of Comparative Sociology, 50(5-6), 419-424. DOI: 10.1177/0020715209339874

SUTER, C. (2010). Globalization, economic and social transformation, and inequality: Introduction to special issue. International Journal of Comparative Sociology, 51(4), 243-245. DOI: $10.1177 / 0020715210378550$

TIWARI, A. K., SHAHBAZ, M., ISLAM, F. (2013). Does financial development increase rural-urban income inequality? Cointegration analysis in the case of Indian economy. International Journal of Social Economics, 40(2), 151-168. DOI: $\underline{10.1108 / 03068291311283616}$

WALlERSTEIN, I., CHASE-DUNN, C., SUTER, C. (2015). Overcoming global inequalities (Vol. 34). Routledge. DOI: 10.4324/9781315633053

YOUNSI, M., BECHTINI, M. (2018). Economic Growth, Financial Development and Income Inequality in BRICS Countries: Evidence from Panel Granger Causality Tests. MPRA Paper No. 85182. 